\title{
Genetic Engineering: Issues of Criminal Law Regulation
}

\author{
OLEG A. BELOV \\ Northwestern Institute (Branch) of Kutafin Moscow State Law University (MSAL), \\ Vologda, Russian Federation
}

ORCID: https://orcid.org/0000-0002-4184-4379, e-mail: belov_oleg@mail.ru

\section{YULIYA N. SPIRIDONOVA}

Vologda Institute of Law and Economics of FSIN Russia, Vologda, Russian Federation

ORCID: https://orcid.org/0000-0003-4466-125X, e-mail: upkiord@yandex.ru

\author{
ALEKSANDR I. ODINTSOV \\ Academy of FSIN Russia, Ryazan, Russian Federation \\ ORCID: https://orcid.org/0000-0002-9234-8973, e-mail: odintsovai@rambler.ru
}

\begin{abstract}
The article analyzes modern scientific achievements in the field of genetic research, considers methods of genetic engineering as an integral part of modern biomedicine, and the issues of human cloning. We examine the differences between reproductive cloning and therapeutic cloning, emphasizing the importance of the latter for improving human life, fighting various diseases, and so on. However, along with ethical problems, there are also problems in the world of legal regulation of genetic research and manipulation of human genes. We touch upon the problems of legal regulation of genome research and human cloning in foreign countries and in the Russian Federation, and, above all, the problems of criminal law regulation of genetic engineering. Based on a comparative analysis of international legal acts, national legislation of a number of countries and regulatory legal acts of the Russian Federation, we conclude that there is insufficient legal regulation of issues related to genetic research in Russia, and, supporting the opinion of a number of scientists, we propose to introduce a number of norms in the Criminal Code of the Russian Federation on criminal liability for socially dangerous behavior in the field of modern methods of biotechnology, genetic engineering, and human cloning.

Key words: gene; genetic research; genetic engineering; methods of genetic engineering; DNA; human cloning; criminal law regulation.

12.00.08 - Criminal law and criminology; penal law.

F or c it a ti o n: Belov O.A., Spiridonova Yu.N., Odintsov A.I. Genetic engineering: issues of criminal law regulation. Penitentiary Science, 2020, vol. 14, no. 4 (52), pp. 556 560. DOI 10.46741/2686-9764-2020-14-4-556-560.
\end{abstract}

At present, we can confidently state the fact that the 21st century has become a century of high-tech industries, high technologies and rapid innovations. The leading positions in the scientific sphere of life today are occupied by the development of genetic research and the application of genetic engineering methods.

Genetic engineering, being an integral part of modern biomedicine, is a set of techniques, methods and technologies for obtaining recombinant RNA and DNA, isolating genes from an organism (cells), manipulating genes, introducing them into other organisms, and grow- ing artificial organisms after removing selected genes from DNA [7]. The essence of genetic engineering lies in biologists' work to isolate certain sections of the DNA molecule, arrange them in new combinations and transfer them from one cell to another. As a result, it is possible to introduce changes to the genome that are unlikely to occur naturally.

Thus, genetic engineering serves to obtain the desired qualities of an altered or a genetically modified organism. In contrast to traditional breeding, in which the genotype is changed only indirectly, genetic engineering 
helps interfere directlywith the genetic apparatus of any organism, using the technique of molecular cloning [3].

Examples of applications of genetic engineering are the production of new genetically modified varieties of grain crops, the production of human insulin, etc. In addition, a number of vaccines have also been genetically engineered and are being tested to reveal their effectiveness against the human immunodeficiency virus (HIV) that causes AIDS. With the help of recombinant DNA, human growth hormone is also obtained in sufficient quantities it the only treatment for such a rare childhood disease as pituitary dwarfism.

Some methods of genetic engineering are already being applied to humans. For example, in the treatment of certain types of infertility in women, the eggs of a healthy woman are used, and as a result, the child inherits the genotype from one father and two mothers.

Genetic engineering technology was applied to humans for the first time to treat Ashanti De Silva, a four-year-old girl who suffered from a severe form of immunodeficiency. Her gene that contained instructions for the production of the adenosine deaminase (ADA) protein was damaged, and without the ADA protein, white blood cells die, leaving the body defenseless against viruses and bacteria. A working copy of the ADA gene was injected into Ashanti's blood cells using a modified virus. The cells were able to independently produce the necessary protein, and within six months the number of white cells in the girl's body increased to a normal level [2]. After that, the field of gene therapy received an impetus for further development.

Since the 1990s, hundreds of laboratories have been conducting research on the use of gene therapy for medical purposes. Today we know that gene therapy can be used to treat diabetes, anemia, and certain types of cancer. For humans, genetic engineering could be used both to treat inherited diseases and to improve the genome.

In the conditions of active development of medical and biological branches of knowledge and possible abuse of their achievements in practice, the problem of human cloning has become very acute [1, p. 82].

Human cloning is a promising technique that consists in creating an embryo and then growing people who have the genotype of an individual, now existing or previously existing, from the embryo.

Technically, at present, this is quite real: biologists have repeatedly performed this kind of action with cells. From an ethical point of view, manipulations with human cells are highly questionable and frowned upon in most cultures. From the point of view of law, human cloning is prohibited in almost all civilized countries of the world [4].

At the same time, depending on the technology, there are two types: reproductive and therapeutic human cloning. The first is the artificial reproduction of a genetically accurate copy of any living creature in the laboratory. With a certain degree of convention, it can be represented as follows: an egg is taken from a female, the nucleus is pulled out of it with a microscopic pipette, then any cell containing the DNA of the cloned organism is inserted into the non-nuclear egg, this cell actually performs the function of a sperm during fertilization of the egg. From the moment the cell merges with the egg, the process of cell reproduction and embryo growth begins.

Thus, the result of reproductive cloning is the birth of a living being (for example, a human child).

Unlike reproductive cloning, therapeutic cloning involves the development of the embryo to the blast cyst stage (up to 14 days), then its growth is stopped. The embryo is used to produce stem cells for their further therapeutic use in medicine, that is, for the treatment and prevention of various diseases [4].

The potential for therapeutic cloning is huge, because stem cells can be used to grow cells from almost all tissues and organs of the human body. Growing individual human organs for their subsequent transplantation is a very promising direction in genetics. This, of course, will significantly reduce the number of criminal acts related to illegal transplantation of human tissues and organs.

Both the permission and the prohibition of cloning have supporters and opponents who give strong arguments to substantiate their opinion [4]. Insufficient regulation of this issue at the legislative level also adds fuel to the fire.

In the legal regulation of activities in the field of genetic engineering, the most important legal documents are international legal acts: the Universal Declaration on the Human Genome and Human Rights, adopted by the UNESCO General Assembly in 1997, the Council of Europe Convention for the protection of Human Rights and Dignity of the Human Being with regard to the Application of Biology and Medicine, and the Convention on Human Rights and Biomedicine, adopted in 1996 by the member states of the Council of Europe.

In 1998, the Committee of Ministers of the Council of Europe approved the additional Pro- 
tocol to the Convention on Human Rights and Biomedicine, Article 1 of which states: "Any intervention to create a human being who is genetically identical to another human being, whether living or dead, is prohibited". The significance of this Protocol is that it for the first time legally defined the position of the international community on the issue of human cloning and gave impetus to the further development of the ban at various levels of legal regulation. However, this document does not establish a difference between reproductive and therapeutic cloning; in practice, this fact hinders the development of various areas of therapeutic cloning aimed at helping sick people.

Currently, the process of criminalizing human cloning is actively going on worldwide. The national legislation of most foreign countries criminalizes only reproductive cloning, but a number of countries explicitly prohibit any type of cloning. For example, in the UK, the relevant criminal provisions are contained in the Human Reproductive Cloning Act 2001, the sanction of which is 10 years of imprisonment. At the same time, therapeutic human cloning is allowed.

In the United States, the ban on cloning was first introduced in 1980. In 2003, the House of Representatives of the US Congress passed a law on the prohibition of human cloning, according to which cloning, aimed at both reproduction and medical research and treatment, is considered a crime, the commission of which is punishable by a 10 -year prison sentence and a fine of 1 million US dollars.

In a number of European countries, such as France, Spain, Estonia, and Moldova, cloning as a crime is enshrined in criminal codes.

In countries such as Brazil, Germany, the UK, and Japan, criminal liability for cloning is established by special laws [5]. For example, the Federal Law of Germany on the protection of embryos of 1990 (The Embryo Protection Act) makes it a criminal act to create an embryo that is genetically identical to another embryo originating from a living or dead person.

In order to bring national legislation in line with the requirements of world practice, the new criminal law of Kazakhstan (adopted on July 3,2014 ), in contrast to the previous criminal code, already provides for criminal liability for human cloning. Thus, Article 129 of the Criminal Code of the Republic of Kazakhstan provides for criminal liability for the commission of human cloning or the use of a human embryo for commercial, military or industrial purposes, as well as the export of germ cells or a human embryo from the Republic of Kazakhstan for the same purposes. The sanction of this article provides for criminal punishment in the form of imprisonment for a term of up to three years with or without deprivation of the right to hold certain positions or engage in certain activities for a term of up to two years. Human cloning committed by a group of persons, or by a group of persons by prior agreement, or by an organized group, or repeatedly, is punishable by imprisonment for a term of four to seven years, with or without the right to hold certain positions or engage in certain activities for a term of up to three years.

Currently, a key role in the legal regulation of this sphere in the Russian Federation is played by Federal Law 86-FZ of July 5, 1996 "On state regulation in the field of genetic engineering". It regulates relations in the field of nature management, environmental protection, environmental safety and human health that arise during the implementation of genetic engineering activities.

It should be noted that this act has been repeatedly criticized by both the legal community and biologists and geneticists. In particular, the lack of elaboration of the terms used, the limited range of regulated relations, and at the same time going beyond them were pointed out. In addition, Russian biologists note the lack of scientific substantiation of the principles of safe use of genetically modified microorganisms, as well as the generally prohibitive nature of legislation in the field of genetic engineering [8, p. 146].

The current legislation provides for the possibility of liability for illegal tampering with human genes. Despite the fact that Russia did not join the Convention on Human Rights and Biomedicine, Russian legislators did not stay away from global trends, responding to the challenge of time by adopting Federal Law No. 54-FZ of May 20, 2002 "On the temporary ban on human cloning", which was extended indefinitely in 2010.

The preamble to this normative legal act states that the law introduces a temporary ban on human cloning, based on the principles of respect for human beings, recognition of the value of the individual, the need to protect human rights and freedoms, and taking into account the insufficiently studied biological and social consequences of human cloning. The prospect of using existing and developing technologies for cloning organisms makes it possible to extend the ban on human cloning or cancel it as scientific knowledge in this area is accumulated, and moral, social and ethical standards are determined when using the appropriate technologies. 
Article 1 of the Federal Law "On the temporary ban on human cloning" contains the following words: "The creation of a human being who is genetically identical to another living or dead human being by transferring the nucleus of a human somatic cell to a nuclear-free female germ cell", therefore, the document refers only to reproductive, and not therapeutic cloning.

According to Article 4 of this law, persons guilty of violating it are prosecuted in accordance with the legislation of the Russian Federation. However, to date, criminal liability measures for human cloning have not been defined by law in Russia.

It is seriously puzzling that the adoption of the Federal Law "On the temporary ban on human cloning" was not accompanied by appropriate amendments to the Criminal Code of the Russian Federation.

In this situation, the ban on reproductive cloning announced by the legislator cannot be implemented effectively, because, according to the doctrine of inter-field relations developed in legal science, regulatory norms need to be promoted by protective norms for their smooth functioning. If the rules of conduct formulated in positive legislation are not guaranteed by state enforcement measures, they cannot be properly implemented, since the subject of regulation remains outside the scope of legal protection [1, p. 84].

Scientists have repeatedly expressed their opinion on the need to establish a criminal ban on human cloning activities. In particular, back in 2006, N.E. Krylova proposed to distinguish crimes committed in the field of biology and medicine from traditional crimes committed by medical professionals in connection with the performance of their professional functions. In her opinion, the objects of bioethical crimes should include, in addition to those already protected by criminal law, such benefits and interests that are currently not protected by Russian criminal law, namely the life and health of the human embryo, the genetic integrity of a person, human dignity in the broad sense of the word, which should be understood as the right to respectful treatment before birth, during life and after death, etc. In her dissertation, N.E. Krylova proposes to introduce criminal liability for human cloning, import or export of cloned human embryos, and interference with the human genotype that is not related to treatment [6].

In 2018, the State Duma of the Russian Federation commissioned a study on the legislative regulation of the use of assisted reproductive technologies (including genome editing, cloning, and surrogacy) to the research team of Kutafin Moscow State Law University (MSAL). The terms of reference draw attention to the fact that the laws on reproductive technologies require further elaboration. Scientists are invited to study foreign legal experience and opportunities for conflict-free development of a new generation of assisted reproductive technologies(ART), the prospects for regulating gene editing for the treatment (prevention) of hereditary (genetic) diseases.

The issue of establishing criminal liability and making amendments and additions to the Criminal Code of the Russian Federation in this part remains open. The rapid development of the field of genetic research in recent years dictates the need to address it at the legislative level in the near future. In our opinion, we should not wait for the first case of illegal activities in the field of genetic research in general and human cloning in particular; it is important to reflect in the Criminal Code of the Russian Federation the norms on criminal liability for committing criminal acts of this kind today.

We consider it timely and necessary to adopt a federal law on introducing amendments to the Criminal Code of the Russian Federation, in order to supplement its Section 7 "Crimes against the person" with the norms providing criminal responsibility for reproductive human cloning, use of human embryos for commercial, military or industrial purposes, and also for the export of a human embryo from the Russian Federation for the same purposes. Thus, we propose to supplement Section 7 as follows:

"Article 120.1. Reproductive human cloning.

1. Reproductive cloning of a human being, i.e. the creation of a living human being who is genetically identical to another living or dead human being, as well as the use of a human embryo for commercial, military or industrial purposes -

shall be punishable... (a medium-gravity crime).

2. Import to the territory of the Russian Federation or export from its territory of cloned human embryos for the same purposes -

shall be punishable... (a medium-gravity crime).

3. Acts provided for in Part 1 or Part 2 of this Article, if they are committed:

a) for personal gain;

b) by a group of persons, a group of persons by prior agreement, or by an organized group;

c) by a person using their official position shall be punishable... (a grave crime)". 


\section{REFERENCES}

1. Blinov A.G. Several ways of criminal lawful act against human cloning. Obshchestvo i pravo = Society and Law, 2014, no. 1 (47), pp. 82-86. (In Russ.).

2. Genetic engineering. Website of the Russian Transhumanist Movement. Available at: http://transhumanism-russia.ru/ content/view/38/135/ (accessed October 12, 2020). (In Russ.).

3. Genetic engineering or Delete the brain: which is more dangerous? Grazhdanskie sily.ru: setevoei zdanie = Civil Forces.ru: Online Edition. Available at: http://gr-sily.ru/nauka/gennaya-inzheneriya-ili-delete-golovnogo-mozga-chto-opasnee-25770.html (accessed October 12, 2020). (In Russ.).

4. Guryleva M.E., Khamitova G.M. Human cloning ethical and legal issues. Kazanskii meditsinskii zhurnal= Kazan Medical Journal, 2019, vol. 100, no. 6, pp. 992-1000. DOI: 10.17816/KMJ2019-992. (In Russ.).

5. Kapinus O.S., Dodonov V.N. Responsibility for human cloning in modern criminal law. In: Sovremennoe ugolovnoe pravo v Rossii i za rubezhom: nekotorye problemy otvetstvennosti: sbornik statei [Modern criminal law in Russia and abroad: some problems of responsibility: a collection of papers]. Moscow: Bukvoed, 2008. Pp. 147-159. (In Russ.).

6. Krylova N.E. Ugolovnoe pravo i bioetika (ugolovno-pravovyeproblemyprimeneniyasovremennykhbiomeditsinskikhte khnologii): avtoreferat dissertatsii na soiskanie uchenoi stepeni doktora yuridicheskikh nauk [Criminal law and bioethics (criminal law problems of application of modern biomedical technologies): Doctor of Sciences (Law) dissertation abstract]. Moscow, 2006. $56 \mathrm{p}$.

7. Panchin A. Defeating God. Populyarnaya mekhanika = Popular Mechanics, 2017, no. 3, pp. 32-35. Available at: http://www.popmech.ru/magazine/2017/173-issue (accessed October 12, 2020). (In Russ.).

8. Shilyuk T.O. The main activities of the federal executive authorities in the field of genetic engineering. Vestnik Universiteta imeni O. E. Kutafina (MGYuA) = Courier of Kutafin Moscow State Law University (MSAL), 2019, no. 6 (58), pp. 145-150. (In Russ.).

\section{INFORMATION ABOUT THE AUTHORS}

OLEG A. BELOV - Candidate of Sciences (Law), Associate Professor, associate professor of the Department of Criminal Law and Criminology, Northwestern Institute (Branch) of Kutafin Moscow State Law University (MSAL), Vologda, Russian Federation. ORCID: https://orcid.org/0000-0002-4184-4379, e-mail: belov_oleg@mail.ru

YULIYA N. SPIRIDONOVA - Candidate of Sciences (Law), Associate Professor, head of the Department of Criminal Procedure, Criminalistics and Intelligence-Gathering Activities at the Legal Faculty of Vologda Institute of Law and Economics of FSIN Russia, Vologda, Russian Federation. ORCID: https://orcid.org/0000-0003-4466-125X, e-mail: upkiord@yandex.ru

ALEKSANDR I. ODINTSOV - Candidate of Sciences (Law), head of higher academic courses, Academy of FSIN Russia, Ryazan, Russian Federation. ORCID: https://orcid.org/0000-0002-9234-8973, e-mail: odintsovai@rambler.ru 